\title{
Isolation, Characterization and Antagonistic Activity of the External Microflora of the House fly, Musca domestica (Diptera: Muscidae)
}

\author{
Fatma H. Galal ${ }^{1,3}$ D, Taghreed ElShammari ${ }^{1}$ and AlaaEddeen M. Seufi ${ }^{2,3 *}$ \\ ${ }^{1}$ Biology Department, College of Science, Jouf University, Kingdom of Saudi Arabia. ${ }^{2}$ Department of Basic Sciences, \\ Deanship of Common First Year, Jouf University, Kingdom of Saudi Arabia. ${ }^{3}$ Department of Entomology, Faculty \\ of Science, Cairo University, Egypt.
}

\begin{abstract}
Experiments were designed to isolate, characterize and study the interaction between external microbiota (bacteria and fungi) carried by adult $M$. domestica after dipping, then removal of the flies from distilled water, sugar solution and saline solution. M. domestica was collected from Sakaka city, Northwestern Saudi Arabia. Three groups of adult $M$. domestica were completely dipped in and then removed from each of the above-mentioned solutions separately. Bacteria and fungi were isolated using corresponding media, characterized using macro and microscopic examinations, and then tested for antagonistic activity. Three bacterial species; Escherichia coli, Bacillus subtilis and Pseudomonas aeruginosa and three fungi; Candida albicans, Rhizopus stolonifer and Aspergillus niger have been isolated, characterized and tested for antagonism. Biochemical tests of bacterial strains confirmed the ability to secrete economically important materials. Different efficiencies to ferment sugars and produce gases have been confirmed, too. Antagonistic tests between microorganisms have revealed that both $E$. coli and $P$. aeruginos $a$ bacteria are antagonists to both $A$. niger and $C$. albicans fungi. However, $R$. stolonifer fungus is antagonist to both $E$. coli and $P$. aeruginosa bacteria. $B$. subtilis bacterium is antagonist to the $\mathbf{3}$ fungi and to the other $\mathbf{2}$ bacteria. The antagonistic activity of our bacterial strains could be attributed to the secretion of antimicrobial materials. Further study on the mechanism of antimicrobial activity of $B$. subtilis strain is recommended. It was concluded that this strain could be useful in controlling some bacterial and fungal infections.
\end{abstract}

Keywords: $M$. domestica, microbiota, bioactive materials, bacterial fungal antagonism.

*Correspondence: alaaseufi@ju.edu.sa

(Received: 02 August 2019; accepted: 05 September 2019)

Citation: Fatma H. Galal, Taghreed ElShammari and AlaaEddeen M. Seufi, Isolation, Characterization and Antagonistic Activity of the External Microflora of the House fly, Musca domestica (Diptera: Muscidae), J Pure Appl Microbiol., 2019; 13(3): $1619-1628$. https://doi.org/10.22207/JPAM.13.3.35

(c) The Author(s) 2019. Open Access. This article is distributed under the terms of the Creative Commons Attribution 4.0 International License which permits unrestricted use, sharing, distribution, and reproduction in any medium, provided you give appropriate credit to the original author(s) and the source, provide a link to the Creative Commons license, and indicate if changes were made. 


\section{INTRODUCTION}

The house fly, Musca domestica, is one of the most common health pests worldwide. $M$. domestica possesses morphological and behavioral characteristics which make it not only annoying, but a mechanical vector of more than 100 pathogens ${ }^{1-10}$. M. domestica is closely related to human activities and it breeds on decaying organic matter such as animal manure, human wastes, open toilets, garbage, foods, vegetables and plants. All of mentioned breading media are full of diverse and active microbial communities ${ }^{3,4,11}$. Many researchers have studied the microbes associated with the wings of some fly species ${ }^{12-14}$. But only one article studied the effect of natural fall and dipping of $M$. domestica on microbial contamination of distilled water and milk ${ }^{15}$.

The present study is based on interaction between the external microbiota (bacteria and fungi) carried by adult $M$. domestica after dipping, then removal of the flies from distilled water, sugar solution and saline solution. Consequently, the antagonism between the isolated strains was investigated.

\section{MATERIALS AND METHODS Collecting flies}

The house fly, M. domestica, were collected from the Sakaka city, AlJouf, Northwestern Saudi Arabia. Collected flies were transported to the laboratory in sterile cups and then they were morphologically identified. $M$. domestica was reared and maintained in the insectary under controlled conditions $\left(27 \pm 2^{\circ} \mathrm{C}\right.$ and $70 \pm 5 \%$ Relative humidity (RH) and 14/10 light/dark photoperiod cycle), according to ${ }^{16}$. These flies were used as a stock for the experimental work.

\section{Solutions used}

The experimental solutions were chosen to represent the normal drinks and foods of the human beings. Distilled water represents the normal drinking water of human. The $10 \%$ sterile sugar solution represents juices and other sugary drinks consumed by human. The $10 \%$ sterile saline solution represents the balanced salting of all types of salads and cooked foods with sauces. All solutions were sterilized using bacterial filters and all tools were autoclaved.

\section{Experimental design}

Three groups of adult $M$. domestica (10 flies/group) were completely dipped in and then removed from each of the following solutions separately: $200 \mathrm{ml}$ of sterilized distilled water (DW), $200 \mathrm{ml}$ of $10 \%$ sterile sugar solution (SU), and $200 \mathrm{ml}$ of $10 \%$ sterile saline solution (SA). Immediately after dipping and removal of flies, bacterial and fungal flora were cultured from the three solutions, separately (DW, SU and SA). One hour later after dipping and removal of flies, bacterial and fungal flora were cultured from the three solutions, separately (DW1, SU1 and SA1). Bacterial isolation using differential media

A fixed volume $(100 \mu \mathrm{l})$ of each of the solutions DW, DW1, SU, SU1, SA and SA1 was spread by sterilized scalpel on $20 \mathrm{~cm}$ diameter plates containing Nutrient agar (NA), Mannitol salt agar (MSA), MacConkey agar, Brilliant green agar (BGA) and Salmonella-Shigella agar (SSA) media, separately. Plates were sealed tightly with parafilm, placed upside down and incubated at $30{ }^{\circ} \mathrm{C}$ for $24-48 \mathrm{~h}$. Plates were then investigated, bacteria were isolated, identified and stored until used in subsequent experiments. Procedure was carried out inside laminar air flow hood ${ }^{17,18}$.

\section{Characterization of the Bacterial Isolates Phenotypic characterization}

Phenotypic characterization of all isolates studied were performed and compared to phenotypic data of known organisms described in the Bergey's Manual of systematic Bacteriology ${ }^{19}$ as well as Gram's staining according to the standard gram staining protocol ${ }^{20}$.

Antagonistic activity between bacterial isolates

Antagonistic activity was tested according to $^{21}$. Briefly, $0.5 \mathrm{ml}$ of a bacterial suspension was spread on the surface of solidified nutrient agar and paper-disc diffusion method ${ }^{22}$ was used for the other bacterial strains. Clear inhibition zones were measured and compared to positive and negative controls. Each experiment was repeated thrice.

\section{Fungal isolation}

A fixed volume $(100 \mu \mathrm{l})$ of the solutions DW, DW1, SU, SU1, SA and SA1 was spread onto $20 \mathrm{~cm}$ diameter plates containing Czapek-Dox's agar medium and Potato Dextrose Agar (PDA) medium, separately. Chloramphenicol $(25.0 \mathrm{mg} /$ L) or Chlortetracycline $(40.0 \mathrm{mg} / \mathrm{L}$ ) was added to the media to inhibit bacterial growth. Plates were 
sealed tightly with parafilm, placed upside down and incubated at $28^{\circ} \mathrm{C}$ for $7-15$ days ${ }^{23}$.

Identification of fungal isolates

Purification of the colonies was carried out by transferring each single colony to a sterile PDA plate and incubating plates at $28^{\circ} \mathrm{C}$ for 7-15 days. The propagated colonies were mounted on slides and stained with lactophenol cotton blue to be examined under light microscope. Macroscopic morphology of mycelium and conidia was observed and used for fungal identification ${ }^{24,25}$.

Antagonism between fungi and associated bacteria

Antagonistic activity was tested according to (26). Briefly, one $\mathrm{ml}$ of each fungus was spread onto the surface of solidified Czapek-Dox's agar media. A paper-disc diffusion method was used as described above ${ }^{22}$. Three replicates were incubated at $30^{\circ} \mathrm{C}$ for 15 days, and inhibition zones were measured and compared to a reference chart.

\section{RESULTS \\ Characterization of bacterial strains}

A total of 18 bacterial isolates were identified during this study from all samples. These isolates were isolated from DW, DW1, SU, SU1, SA and SA1. Isolates were definitely characterized as three species; Escherichia coli, Bacillus subtilis and Pseudomonas aeruginosa (Table 1).

Table 1. Isolation of bacterial species from different solutions after dipping and removal of $M$. domestica immediately and one hour later

\begin{tabular}{|c|c|c|c|c|c|c|}
\hline Solution & DW & SU & SA & DW1 & SU1 & SA1 \\
\hline \multicolumn{7}{|c|}{ Bacterial Species } \\
\hline E. coli & $\sqrt{ }$ & $\sqrt{ }$ & $\sqrt{ }$ & $\sqrt{ }$ & $\sqrt{ }$ & $\sqrt{ }$ \\
\hline P. aeruginosa & $\sqrt{ }$ & $\sqrt{ }$ & $\sqrt{ }$ & $\sqrt{ }$ & $\sqrt{ }$ & $\sqrt{ }$ \\
\hline B. subtilis & $\sqrt{ }$ & $\sqrt{ }$ & $\sqrt{ }$ & $\sqrt{ }$ & $\sqrt{ }$ & $\sqrt{ }$ \\
\hline
\end{tabular}

Morphological characterization of bacterial colonies

Shapes, sizes, elevation, opacity and margins of the bacterial colonies are summarized in Table (2). All colonies were elevated and opaque except the translucent colony of $E$. coli. Circular colonies of $E$. coli and $P$. aeruginosa and irregular $B$. subtilis colony were observed, too. In addition, small-sized with entire margin colonies of $E$. coli, medium-sized with undulate margin colonies of $P$. aeruginosa and large-sized with lobate margin colonies of $B$. subtilis were noticed (Table 2 ).

Gram characteristics of the bacterial species

Table (3) summarizes Gram's staining and cell morphology of the bacterial species.
All bacterial cells were Gram-negative except $B$. subtilis which was Gram-positive. Meanwile, all cells were rod-shaped except $P$. aeruginosa which were coccobacilli.

Biochemical characterization of bacterial species Specific biochemical assays were carried out to evaluate economic and commercial values of the species. All bacterial species secrete catalase, $B$. subtilis and $P$. aeruginosa secrete oxidase and only $B$. subtilis secretes urease (Table 4). These enzymes can be commercially harnessed and marketed.

IMViC tests indicated that only $E$. coli secretes tryptophanase enzyme and indole. Additionally, E. coli is glucose-acidic-fermenter.

Table 2. Colony characteristics of the isolated bacterial species

\begin{tabular}{|c|c|c|c|c|c|}
\hline Colony Characteristic & Shape & Size & Elevation & Opacity & Margin \\
\hline \multicolumn{6}{|l|}{ Bacterial Species } \\
\hline E. coli & Circular & Small & Raised & Translucent & Entire \\
\hline P. aeruginosa & Circular & Medium & Raised & Opaque & Undulate \\
\hline B. subtilis & Irregular & Large & Raised & Opaque & Lobate \\
\hline
\end{tabular}


Table 3. Gram's characteristics and cell morphology of the isolated bacterial species

\begin{tabular}{lll}
\hline Cell parameters & Cell Gram Character & Cell Morphology \\
\hline Bacterial species & & \\
E. coli & -ve & Rod shaped \\
P. aeruginosa & - ve & Coccobacilli \\
B. subtilis & +ve & Rod shaped \\
\hline
\end{tabular}

Table 4. Biochemical characteristics of the isolated bacterial species

\begin{tabular}{|c|c|c|c|}
\hline Bacteria & E. coli & P. aeruginosa & B. subtilis \\
\hline \multicolumn{4}{|l|}{ Biochemical test } \\
\hline Catalase & + ve & +ve & +ve \\
\hline Oxidase & -ve & +ve & + ve \\
\hline Urease & -ve & -ve & +ve \\
\hline Tryptophanase & + ve & -ve & -ve \\
\hline Indole & +ve & -ve & -ve \\
\hline Glucose fermentation & +ve Acidic & +ve Alkaline & +ve Alkaline \\
\hline Sucrose fermentation & -ve & -ve & +ve Alkaline \\
\hline Lactose fermentation & +ve Acidic & -ve & -ve \\
\hline TSI- test & +ve Acidic & -ve & +ve Acidic \\
\hline $\mathrm{CO}_{2}$ production & +ve & -ve & -ve \\
\hline $\mathrm{H}_{2} \mathrm{~S}$ production & + ve & -ve & -ve \\
\hline
\end{tabular}

However, both $B$. subtilis and $P$. aeruginosa are glucose-alkaline-fermenters. Sugar fermentation tests revealed that $E$. coli and $P$. aeruginosa are non-sucrose-fermenters. Both $B$. subtilis and $P$. aeruginosa are non-lactose-fermenters (Table 4). In addition, $\mathrm{TSI}$ and $\mathrm{H}_{2} \mathrm{~S}$ tests revealed that $B$. subtilis is trisugar-acidic-fermenter lacking both $\mathrm{CO}_{2}$ and $\mathrm{H}_{2} \mathrm{~S}$ gas production. $E$. coli is trisugaracidic-fermenter producing $\mathrm{CO}_{2}$ and lacking $\mathrm{H}_{2} \mathrm{~S}$ gas production. Whilst, $P$. aeruginosa is non-trisugarfermenter (Table 4).

Table 5. Colony characterization by using differential media

\section{Characterization by differential media}

In order to differentiate between the obtained bacterial species, 5 differential media were employed. Bacterial growth and characteristic colors of bacterial colonies were summarized in Table (5). Three growths with two characteristic colors were observed with MacConkey agar, two growths with two characteristic colors with NA media, only one growth with a characteristic color was observed with SSA, BGA and MSA media (Table 5). Insufficient characterization has been observed when using differential media.

\begin{tabular}{lll}
\hline Media & Bacteria & Color \\
\hline MacConkey agar & Tow growths; & \\
& E. coli & Pink colonies. \\
& P. aeruginosa & Colorless colonies with dark centers. \\
MSA & E. coli & Pink colonies. \\
SSA & E. coli & Pink colonies. \\
BGA & E. coli & Greenish colonies. \\
NA & Tow growths; & \\
& B. subtilis & Creamy or brown color colonies. \\
& P. aeruginosa & Greenish color colonies.
\end{tabular}


Antagonistic activity between bacterial species

Growth of two or more microorganisms in a single culture medium may indicate synergistic activity. However, growth of a single species on the medium may indicate antagonistic activity of the growing species. Our results revealed that B. subtilis is antagonistic to both $E$. coli and $P$. aeruginosa (Table 6).

Table 6. Antagonistic activity of the isolated bacterial species

\begin{tabular}{lll}
\hline Bacterial combination & Antagonistism & Growths \\
\hline E. coli + P. aeruginosa & -ve & Two growths and no inhibition \\
E. coli + B. subtilis & $+\mathrm{ve}$ & Growth of $B$. subtilis only \\
P. aeruginosa + B. subtilis & $+\mathrm{ve}$ & Growth of $B$. subtilis only \\
E. coli+ P. aeruginosa+ B. subtilis & $+\mathrm{ve}$ & Growth of $B$. subtilis only \\
\hline
\end{tabular}

\section{Fungal isolation}

A total of ten fungal isolates were isolated during the current work. Only one isolate from DW and DW1, two isolates from SU and SU1, two isolates from SA and SA1 were isolated. Fungal isolates were identified as Candida albicans, Rhizopus stolonifer and Aspergillus niger (Table 7). C. albicans was persistent in all solutions, $R$. stolonifer appeared in sugar solutions and $A$. niger grew in salt solutions (Table 7).

\section{Characterization of fungal isolates \\ Macroscopic and microscopic characterization}

Table (7) clarified that all fungal isolates were identified to three different species; $C$. albicans was isolated from all solutions ( 6 isolates), $R$. stolonifer was isolated from sugar solutions ( 2 isolates) and $A$. niger was isolated from salt solutions ( 2 isolates). Table (8) summarizes the macroscopic and microscopic characteristics of the isolated fungi. C. albicans appeared as white non-

Table 7. Isolation of fungal species from different solutions after dipping and removal of M. domestica immediately and one hour later

\begin{tabular}{lcccccc}
\hline Solution & DW & SU & SA & DW1 & SU1 & SA1 \\
\hline Fungal Species & $\sqrt{ }$ & $\sqrt{ }$ & $\sqrt{ }$ & $\sqrt{ }$ & $\sqrt{ }$ & $\sqrt{ }$ \\
C. albicans & - & $\sqrt{ }$ & - & - & $\sqrt{ }$ & - \\
R. stolonifer & - & - & $\sqrt{ }$ & - & - & $\sqrt{ }$ \\
A. niger & & & &
\end{tabular}

branching globular structures with pseudohyphae. $R$. stolonifer appeared as dense, cottony structures which fill culture plate. Branched aerial mycelia with filamentous non-septate hyphae were observed. Sporangia with many spores are carried by sporangiophores. A. niger was reported as dichotomous branched mycelia with septate hyphae. Numerous black spores are carried by long, smooth and hyaline conidiophores (Table 8). Antagonistic activity

$E$. coli and $P$. aeruginosa bacteria prohibited growths of both $A$. niger and $C$. albicans, whatever bacteria have applied individually or in combination. However, R. stolonifer prohibited growths of $E$. coli and $P$. aeruginosa whatever applied to the fungus individually or mixed with each other. Interestingly, B. subtilis bacteria prohibited the growths of all fungi whatever it has applied individually or in combination with other bacteria (Table 9).

\section{DISCUSSION}

The current study presents 3 bacterial and 3 fungal colonies with distinct morphological characters were identified. Two Gram negative Proteobacteria; E. coli (Enterobacteriales, Enterobacteriaceae) and $P$. aeruginosa (Pseudomonadales, Pseudomonadaceae) and one Gram positive Firmicutes bacteria; $B$. subtilis (Bacillales, Bacillaceae) were isolated. In addition, 2 
Table 8. Macroscopic and microscopic characterization of the isolated fungi

\begin{tabular}{|c|c|c|c|}
\hline Fungi & A. niger & R. stolonifer & C. albicans \\
\hline On agar plate & $\begin{array}{l}\text { Powdery structures } \\
\text { with numerous } \\
\text { black dots. }\end{array}$ & $\begin{array}{l}\text { Dense, cottony, } \\
\text { aerial mycelia fill } \\
\text { the plate. It appears } \\
\text { white then became grey. }\end{array}$ & White colony. \\
\hline Branching & $\begin{array}{l}\text { Dichotomous } \\
\text { branching. }\end{array}$ & Branched. & Non-branching. \\
\hline Hyphae & $\begin{array}{l}\text { Septate and } \\
\text { hyaline. }\end{array}$ & $\begin{array}{l}\text { Non-septate. } \\
\text { Stolons connecting } \\
\text { fungal bodies. }\end{array}$ & Pseudohyphae. \\
\hline Conidiophores & $\begin{array}{l}\text { Conidiophores } \\
\text { are long, smooth, } \\
\text { hyaline and darker } \\
\text { at the apex. }\end{array}$ & $\begin{array}{l}\text { Noticeable } \\
\text { sporangiophores. }\end{array}$ & Absent. \\
\hline Spores & Numerous and black. & $\begin{array}{l}\text { Globose sporangia } \\
\text { with many spores, } \\
\text { and flattened base. } \\
\text { Grayish black and } \\
\text { powdery in appearance. }\end{array}$ & $\begin{array}{l}\text { Reproduction by } \\
\text { budding. }\end{array}$ \\
\hline
\end{tabular}

Table 9. Antagonistic activity between fungi and bacteria

\begin{tabular}{|c|c|c|c|}
\hline Bacteria & Fungi & Antagonism & Growths \\
\hline E. coli & A. niger & + ve & Growth of E. coli \\
\hline P. aeruginosa & & + ve & Growth of $P$. aeruginosa \\
\hline B. subtilis & & + ve & Growth of $B$. subtilis \\
\hline E. coli $+P$. aeruginosa & & $+v e$ & Growth of $E$. coli $+P$. aeruginosa \\
\hline E. coli + B. subtilis & & + ve & Growth of $B$. subtilis \\
\hline P. aeruginosa $+B$. subtilis & & +ve & Growth of $B$. subtilis \\
\hline E. coli $+P$. aeruginosa $+B$. subtilis & & + ve & Growth of $B$. subtilis \\
\hline E. coli & R. stolonifer & + ve & Growth of $R$. stolonifer \\
\hline$P$. aeruginosa & & $+v e$ & Growth of $R$. stolonifer \\
\hline B. subtilis & & +ve & Growth of $B$. subtilis \\
\hline E. coli $+P$. aeruginosa & & + ve & Growth of $R$. stolonifer \\
\hline E. coli $+B$. subtilis & & + ve & Growth of $B$. subtilis \\
\hline P. aeruginosa $+B$. subtilis & & + ve & Growth of $B$. subtilis \\
\hline E. coli $+P$. aeruginosa $+B$. subtilis & & + ve & Growth of $B$. subtilis \\
\hline E. coli & C. albicans & + ve & Growth of E. coli \\
\hline P. aeruginosa & & + ve & Growth of $P$. aeruginosa \\
\hline B. subtilis & & $+v e$ & Growth of $B$. subtilis \\
\hline E. coli $+P$. aeruginosa & & + ve & Growth of $E$. coli $+P$. aeruginosa \\
\hline E. coli $+B$. subtilis & & + ve & Growth of $B$. subtilis \\
\hline P. aeruginosa $+B$. subtilis & & $+v e$ & Growth of $B$. subtilis \\
\hline E. coli $+P$. aeruginosa $+B$. subtilis & & + ve & Growth of $B$. subtilis \\
\hline
\end{tabular}

Ascomycotic fungi; C. albicans (Saccharomycetales, authors from 1912 up till now. Due its accessibility Saccharomycetaceae), A. niger (Eurotiales, to humane living, special attention to house fly Trichocomaceae) and one Zygomycotic fungus; was markedly noticeable. Several authors have R. stolonifer (Mucorales, Mucoraceae). Bacterial isolated more than 32 bacterial genera including association with flies is attracting subject to our species from the house fly; $M$. demestica. The 
reported 32 genera belong to 3 phyla, 12 orders and 21 families within bacterial kingdom (e.g. 10, 27-42). In parallel, more than 21 fungal genera including our species have been isolated from the house fly; $M$. demestica. The reported 21 genera belong to 4 phyla, 13 orders and 12 families within fungal kingdom (e.g. 33, 43-49). More than 100 species of parasites and microorganisms have been isolated from the house fly ${ }^{36,37}$. Authors have paid attention to the bacterial communities of other flies $^{50-52}$.

The antagonistic activity of our bacterial strains could be interpreted by the ability of bacteria to secrete enzymes and other economic materials as shown in biochemical characterization. Antagonistic tests between microorganisms have revealed that both $E$. coli and $P$. aeruginosa bacteria are antagonists to $A$. niger and $C$. albicans fungi. Agreeable results have been presented by ${ }^{51}$ who revealed that $E$. coli secretes a fungicide that kills $C$. albicans. Also $P$. aeruginosa was reported as antagonist to $A$. niger ${ }^{53}$. Other studies have reported that $P$. aeruginosa is antagonist to Aspergillus fumigatus in planktonic growth ${ }^{54}$ and in bio $\mathrm{Im}$, too $^{55-58}$. Contrary to our results, no antagonism between $E$. coli and $C$. albicans has been found ${ }^{26}$. Interestingly, $P$. aeruginosa and $A$. fumigatus have been reported to possess mutual antagonism at different stages of bio $\mathrm{Im}$ development ${ }^{59}$. Recently, the complexity beyond the simple antagonistic interaction between $P$. aeruginosa and $C$. albicans has been intensively reviewed ${ }^{60}$. E. coli, Pseudomonas sp. and Bacillus sp. have been reported as antagonists to $A$. niger and could be used in biocontrol of the fungus ${ }^{61}$. E. coli has exhibited antagonistic activity to pathogenic Aspergillus spp. ${ }^{62}$. However, $R$. stolonifer fungus is antagonist to $E$. coli and $P$. aeruginosa bacteria. A previous study has presented that $R$. stolonifer fungus showed antagonistic effect to $A$. niger and $C$. albicans fungi and to $P$. aeruginosa and $E$. coli bacteria. This activity was attributed to toxic secondary metabolites secreted by the fungus ${ }^{63}$. $B$. subtilis bacterium is antagonist to the 3 fungi and to the other 2 bacteria. In antagonistic study, B. subtilis has proved to produce a biosurfactant that prohibited the growth of Salmonella, Shigella and Staphylococcus bacteria ${ }^{64}$. Antifungal activity of Bacillus isolates against phytopathogenic fungi may be attributed to the cyclic lipopeptide; fungycin which plays important role in this process $^{65-68}$. Recently, the antimicrobial compounds of $B$. subtilis have been intensively reviewed ${ }^{69}$. No microbial competition between bacteria and fungi was recorded in the present study. However, microbial competition after natural falling and dipping of house fly in water and milk has been reported ${ }^{15}$. The total number of microbes has decreased within one hour after dipping in the case of water. Meanwhile, immediate decrease in total number of microbes in the case of milk has been reported ${ }^{15}$. Further research on the effect of falling and dipping of $M$. domestica using electron microscopy and molecular techniques is recommended.

Overall, the current work presents isolation, characterization and antagonistic activity of six microorganisms isolated from external surface of the house fly; $M$. domestica after dipping in DW, SU and SA solutions. Our results revealed that our bacterial strains secrete many economically important materials which could be harnessed and marketed. Different efficiencies of sugar fermentation and gas production have been observed, too. In addition the antagonistic activity, especially the ability of $B$. subtilis bacterium to prohibit growth of all bacterial and fungal strains could be interpreted in the light of its production of bioactive materials. Further study on the mechanism of antimicrobial activity of $B$. subtilis strain is recommended. We concluded that this strain could be useful in controlling some bacterial and fungal infections.

\section{ACKNOWLEDGEMENTS}

We thank Dr. Shaymaa Nabil for her technical support.

\section{CONFLICTS OF INTEREST}

conflict of interest.

The authors declares that there is no

\section{AUTHORS' CONTRIBUTION}

Conceived and designed the experiments: FHG, AMS. Performed the experiments: FHG, AMS, TES. Analyzed the data: FHG, AMS. Wrote the paper: AMS, FHG. All authors have approved the final manuscript. 


\section{FUNDING}

None.

\section{DATA AVAILABILITY}

All datasets generated or analyzed during this study are included in the manuscript.

\section{ETHICS STATEMENT}

Not applicable.

\section{REFERENCES}

1. Gupta SR, Rao CK, Biswas H, Krishnaswami AK, Wattal BL, Raghavan NG. Role of the house fly in the tramsmission of intestinal parasitic cysts-ova. Indian J Med Res 1972; 8:1120 - 1125 .

2. Zurek L, Schal C, Watson DW. Diversity and contribution of the intestinal bacterial community to the development of Musca domestica (Diptera: Muscidae) larvae. J Med. Entomol 2000; 37: 924-928. https:// doi.org/10.1603/0022-2585-37.6.924

3. Graczyk TK, Knight R, Gilman RH, Cranfield MR. The role of non-biting flies in the epidemiology of human infectious diseases. Microbes. Infect. 2001; 3: 231235. https://doi.org/10.1016/S1286-4579(01)01371-5

4. Moon RD. Muscid flies (Muscidae). Medical and Veterinary Entomology (Mullen G \& Durden L, eds), Elsevier Science, San Diego, CA. 2002; pp. 279-301. https://doi.org/10.1016/B978-012510451-7/50016-5

5. Alam MJ Zurek L. Association of Escherichia coli 0157:H7 with houseflies on a cattle farm. Appl Environ Microbiol. 2004; 70: 7578-7580. https://doi. org/10.1128/AEM.70.12.7578-7580.2004

6. Rahuma N, Ghenghesh KS, Ben Aissa R, Elamaari A. Carriage by the housefly (Musca domestica) of multipleantibiotic- resistant bacteria that are potentially pathogenic to humans, in hospital and other urban environments in Misurata, Libya. Ann. Trop Med Parasitol, 2005; 99: 795-802. https://doi. org/10.1179/136485905X65134

7. Macovei L, Zurek L. Ecology of antibiotic resistance genes: characterization of enterococci from houseflies collected in food settings. Appl Environ Microbiol. 2006; 72: 4028-4035. https://doi.org/10.1128/ AEM.00034-06

8. Macovei L, Miles B, Zurek L. The potential of house flies to contaminate ready-to-eat food with antibiotic resistant enterococci. J Food Protect. 2008; 71: 432439. https://doi.org/10.4315/0362-028X-71.2.435

9. Chakrabarti S, Kambhampati S, Zurek L. Assessment of house fly dispersal between rural and urban habitats in Kansas, USA. J. Kans. Entomol. Soc. 2010; 83: 172-188. https://doi.org/10.2317/JKES0809.15.1

10. Ahmad A, Ghosh A, Schal C, Zurek L. Insects in confined swine operations carry a large antibiotic resistant and potentially virulent enterococcal community. B.M.C. Microbiol. 2011; 11: 23. https://doi.org/10.1186/14712180-11-23

11. Greenberg B, Kowalski JA, Klowden MJ. Factors Affecting the Transmission of Salmonella by Flies:
Natural Resistance to Colonization and Bacterial Interference. Infect Immun. 1970; 2(6):800-9.

12. Aj-Taili SI, Al-Misnid AAR, Al-Uteybi KD. Wing One and the Other Disease Carrying the Cure. Qassim University. Danny Kingsley. 2002.

13. Al-Sammak E, Al-Taei K. Isolation and Identification of Bacterial Species from House Fly Musca domestica Wings. J Sci Rafidain. 2011; 22(3): 11-21.

14. Atta MR. Microbiological Studies on Fly Wings (Musca domestica) Where Disease and Treat. World J Med Sci. 2014; 11(4): 486-489.

15. Baeshin NA, Sejiny MJ, Zaki M, AbdelHafez A.M. Effect of natural falling and dipping of house fly (Musca domestica) on the microbial contaimmation of water and milk. J k a u sci. 1990; 2: 45- 52. https://doi. org/10.4197/Sci.2-1.3

16. Hashem HO, Youssef NS. Developmental changes induced by methanolic extracts of leaves and fruits of Melia azedarach L. on the house fly, Musca domestica vicina Macq. J Egypt Ger Soc Zool. 1991; 3(E): 35-52.

17. Thiery I, Frachon E. Identification, isolation, culture and preservation of entomopathogenic bacteria. In: Lacey AL ed. Manual of techniques in insect pathology. London, Academic Press. 1997; Pp. 55-73. https://doi. org/10.1016/B978-012432555-5/50006-3

18. Davari B, Kalantar E, Zahirnia A, Moosa-Kazemi SH. Frequency of Resistance and Susceptible Bacteria Isolated from Houseflies. Iran J Arthropod Borne Dis. 2010; 4(2):50-5.

19. Noel R. Bergey's Manual of Systematic Bacteriology. Gros Ver Berlin. 1985; 28: 222-231. https://doi. org/10.1111/j.1439-0507.1985.tb02120.x

20. Gram C. Ueber die isolirteFinrbung der Schizomyceten in Schnitt-und Trockenprinparaten. Fortschritte der Medcin. 1884; 2: 185-189.

21. Galal FH, Abu elnasr A, Abdallah I, Seufi AEM, Zaki O. Isolation and Characterization of Internal Bacteria from the Mosquito, Culex pipiens from Egypt. Inter J Sci Res 2015; 4: 2682-8.

22. OIE. Laboratory methodologies for bacterial antimicrobial susceptibility testing. OIE Terrestrial Manual. Paris, France: World Organization for Animal Health. 2012.

23. Ozdal M, Incekara U, Polat A, Gur O, Kurbanoulu EB,Tasar GE. Isolation of filamentous fungi associated with two common edible aquatic insects, Hydrophilus Piceus and Dytiscus Marginalis. J Bio Micro 2012; 1: 95-105.

24. Arx JA. The genera of fungi sporulating in pure culture. 3rdedn. J. Cramer, Berlin 1981; pp. 387.

25. Watanabe T. Pictoral atlas of soil and seed fungi: morphologies of cultured fungi and key to species. $2^{\text {nd }}$ Edition. CRC Press, Boca Raton London New York Washington, DC. 2002. https://doi. org/10.1201/9781420040821

26. Galal FH, Abu elnasr A, Abdallah I, M, Zaki O.\& Seufi AE. Culex (Culex) Pipiens Mosquitoes Carry and Harbor Pathogenic Fungi during Their Developmental Stages. Erciyes Med J 2017; 39(1): 1-6 . DOI: 10.5152/etd.2017.16067. https://doi.org/10.5152/ etd.2017.16067

27. Torrey JC. Numbers and types of bacteria carried by 
city flies. J. Infect Dis. 1912 ; 10: 166-177. https://doi. org/10.1093/infdis/10.2.166

28. Greenberg B. Flies and Diseases Vol II, Biology and Disease Transmission. Princeton University Press Princeton NJ. 1973.

29. Sulaiman S, Aziz AH, Hashim Y, Abdul Rahim S. Isolations of entero-pathogenic bacteria from some cyclorrhaphan flies in Malaysia. Malaysian Appl Biol 1988; 17(2):129-133. https://doi. org/10.1111/j.1365-2915.1988.tb00043.x

30. Grubel P, Hoffman JS, Chong FK, Burstein NA, Chandrakant M, Cave DA. Vector Potential of Houseflies (Musca domestica) for Helicobacter pylori. J Clini Microbiol. 1997; 35(6): $1300-1303$.

31. Vazirianzadeh B, Setareh S, Mahmoud R, Hajhossien R, Manijeh M. Identification of bacteria which possible transmitted by Musca domestica (Diptera: Muscidae) in the region of Ahvaz, SW Iran. Jundishapur J Microbiol. 2008 ; 1(1): 28-31.

32. Butler JF, Garcia-Maruniak A, Meek F, Maruniak JE. Wild Florida house flies (Musca Domestica) as carriers of pathogenic bacteria. Florida Entomol. 2010; 93(2):218-23. https://doi.org/10.1653/024.093.0211

33. Davari B, Khodavisy S, Alaa F. Isolation of fungi from housefly (Musca domestica L.) at Slaughter House and Hospital in Sanandaj, Iran. J prev med Hyg. 2012; 53: 172-174.

34. Shukla S, Chopra S, Ther SV, Sharma R, Sikrodia R. Isolation and identification of enterobacterial species from Musca domestica in broiler farms of Madhya Pradesh. Vet Practitioner. 2013; 14(2):239-41.

35. Bahrndorff S, Gill C, Lowenberger C, Skovgırd H, Hald $B$. The effects of temperature and innate immunity on transmission of Campylobacter jejuni (Campylobacterales: Campylobacteraceae) between life stages of Musca domestica (Diptera: Muscidae). J Med Entomol. 2014; 51(3):670-7. https://doi. org/10.1603/ME13220

36. Nassiri H, Zarrin M, Veys-Behbahani R, Faramarzi S, Nasiri A. Isolation and identification of pathogenic filamentous fungi and yeasts from adult house fly (Diptera: Muscidae) captured from the hospital environments in Alivaz city, Southwestern Iran. J Med Entomol. 2015; 52(6):1351-6. https://doi. org/10.1093/jme/tjv140

37. Tsagaan A, Kanuka I, Okado K. Study of pathogenic bacteria detected in fly samples using universal primermultiplex PCR. Mongolian J Agri Sci. 2015; 15(2):27-32. https://doi.org/10.5564/mjas.v15i2.541

38. Eke SS, Idris AR, Omalu ICJ, Otuu CA, Ibeh EO, Ubanwa $E D$, Luka J, Paul S. Relative abundance of synanthropic flies with associated parasites and pathogens in Minna Metropolis, Niger State. Nigeria. Nigerian J Parasitol. 2016; 37(2):142-6. https://doi.org/10.4314/njpar. v37i2.4

39. Ranjbar R, Izadi M, Hafshejani TT, Khamesipour F. Molecular detection and antimicrobial resistance of Klebsiella pneumoniae from house flies (Musca domestica) in kitchens, farms, hospitals and slaughterhouses. J Infect Public Health. 2016; 9(4):499505. https://doi.org/10.1016/j.jiph.2015.12.012

40. Bahrndorff $S$, de Jonge N, Skovgırd H, Nielsen JL.
Bacterial Communities Associated with Houseflies (Musca domestica L.) Sampled within and between Farms. PLOS ONE. 2017; 12(1):e0169753. https://doi. org/10.1371/journal.pone.0169753

41. Gill C, Bahrndorff S, Lowenberger C. Campylobacter jejuni in Musca domestica: An examination of survival and transmission potential in light of the innate immune responses of the house flies. Insect Sci. 2017; 24(4): 584-98. https://doi.org/10.1111/17447917.12353

42. Ommi D, Hemmatinezhad B, Hafshejani TT, Khamesipour F. Incidence and antimicrobial resistance of Campylobacter and Salmonella from houseflies (Musca domestica) in kitchens, farms, hospitals and slaughter houses. Proc Natl Acad Sci India Sect B Biol Sci. 2017; 87(4):1285-1291. https://doi.org/10.1007/ s40011-016-0705-3

43. Fyrster M, Klimpel S, Sievert K. The house fly (Musca domestica) as a potential vector of metazoan parasites caught in a pig-pen in Germany. Veterinary Parasitol. 2009; 160(1-2):163-7. https://doi.org/10.1016/j. vetpar.2008.10.087

44. Kumara HNS, Murali S, Thyagaraj NE, Ghosh SK. Survey and Isolation of natural incidence of different fungal pathogens against house flies in different urban habitats. J Biopest. 2013; 6(2):133-8.

45. Phoku JZ, Bernard TG, Potgieter N, Dutton MF. Fungi in housefly (Musca domestica L.) as a disease risk indicator - A case study in South Africa. Acta Tropica. 2014; 140: 158-65. https://doi.org/10.1016/j. actatropica.2014.08.019

46. Kassiri H, Zarrin M, Veys-Behbahani R, Faramarzi S, Kasiri A. Isolation and Identification of Pathogenic Filamentous Fungi and Yeasts From Adult House Fly (Diptera: Muscidae) Captured From the Hospital Environments in Ahvaz City. Southwestern Iran. J Med Entomol. 2015; 52(6):1351-6. https://doi. org/10.1093/jme/tjv140

47. Awache I, Farouk AA. Bacteria and fungi associated with houseflies collected from cafeteria and food Centres in Sokoto. FUW Trends Sci Technol J. 2016; 1(1):123-5.

48. Phoku JZ, Barnard TG, Potgieter N, Dutton MF. Fungal dissemination by housefly (Musca domestica L.) and contamination of food commodities in rural areas of South Africa. Int J Food Microbiol. 2016; 217:177-81. https://doi.org/10.1016/j.ijfoodmicro.2015.10.028

49. Ysquierdo CA, Olafson PU, Thomas DB. Fungi Isolated From House Flies (Diptera: Muscidae) on Penned Cattle in South Texas. J Med Entomol. 2017; 54(3):705-11. https://doi.org/10.1093/jme/tjw214

50. Zhao $Y$, Wang $W$, Zhu $F$, Wang $X$, Wang $X$, Lei $C$. The gut microbiota in larvae of the housefly Musca domestica and their horizontal transfer through feeding. AMB Express. 2017; 7:147. doi:10.1186/ s13568-017-0445-7. https://doi.org/10.1186/s13568017-0445-7

51. Cabral DJ, Penumutchu S, Norris C, Morones-Ramirez $J R$, Belenky P. Microbial competition between Escherichia coli and Candida albicans reveals a soluble fungicidal factor. Microb Cell. 2018; 5(5): 249-255. https://doi.org/10.15698/mic2018.05.631 
52. Blow F, Gioti A, Goodhead IB, Kalyva M, Kampouraki A, Vontas J, Darby AC. Functional genomics of a symbiotic community: shared traits in the olive fruit fly gut microbiota. https://doi.org/10.1101/590489

53. Khanuchiya, S, Parabia, FM, Patel M, Patel V, Patel $\mathrm{K}$, Gami B. Effect of Pseudomonas fluorescence,P. aeruginosa and Bacillus subtilis as biocontrol agentfor crop protection. Cibtech J Microbiol. 2012; 1(1): 52-59.

54. Briard B, Heddergott C, Latg' J-P. Volatile compounds emitted by Pseudomonas aeruginosa stimulate growth of the fungal pathogen Aspergillus fumigatus. $M$ Bio. 2016; 7: e00219. https://doi.org/10.1128/ mBio.00219-16

55. Mowat E, Rajendran R, Williams C, McCulloch E, Jones $\mathrm{B}$, Lang $\mathrm{S}$. Pseudomonas aeruginosa and their small diffusible extracellular molecules inhibit Aspergillus fumigatus biofilm formation. FEMS Microbiol Lett. 2010; 313: 96-102. https://doi.org/10.1111/j.15746968.2010.02130.x

56. Briard B, Bomme P, Lechner BE, Mislin GLA, Lair V, Pr 'vost M-C. Pseudomonas aeruginosa manipulates redox and iron homeostasis of its microbiota partner Aspergillus fumigatus via phenazines. Sci Rep. 2015; 5: 8220. https://doi.org/10.1038/srep08220

57. Ferreira JAG, Penner JC, Moss RB, Haagensen JAJ, Clemons KV, Spormann AM . Inhibition of Aspergillus fumigatus and its biofilm by Pseudomonas aeruginosa is dependent on the source, phenotype and growth conditions of the bacterium. PloS One. 2015; 10: e0134692. https://doi. org/10.1371/journal.pone.0134692

58. Shirazi F, Ferreira JA, Stevens DA, Clemons K V, Kontoyiannis DP. Biofilm filtrates of pseudomonas aeruginosastrains isolated from cystic fibrosis patients inhibit preformed Aspergillus fumigatus biofilms via apoptosis. PLoS One 2016; 11: e0150155. https://doi. org/10.1371/journal.pone.0150155

59. Reece E, Segurado R, Jackson A, McClean S, Renwick J, Greally P. Co-colonisation with Aspergillus fumigatus and Pseudomonas aeruginosa is associated with poorer health in cystic fibrosis patients: an Irish registry analysis. BMC Pulm. Med. 2017; 17: 70. https://doi. org/10.1186/s12890-017-0416-4

60. Fourie R, Pohl C. Beyond Antagonism: The Interaction Between Candida Species and Pseudomonas aeruginosa. J Fungi 2019; 5(2): 34 . https://doi. org/10.3390/jof5020034

61. Rao MS, Kamalnath M, Umamaheswari R, Rajinikanth
R, Prabu P, Priti K, Grace GN, Chaya MK, Gopalakrishnan C. Bacillus subtilis IIHR BS-2 enriched vermicompost controls root knot nematode and soft rot disease complex in carrot. Sci Hortic. 2017;218:56-62. https://doi.org/10.1016/j.scienta.2017.01.051

62. Kr ger W, Vielreicher S, Kapitan M, Ilse DJ, Niemiec MJ. Fungal-Bacterial Interactions in Health and Disease. Pathogens 2019; 8(2): 70. https://doi.org/10.3390/ pathogens 8020070

63. Sohail MA, Iqbal Z, Sheena SMK, Inayat UR, Waqar K , Ali A , Imran U , Muhammad N. Antimicrobial activity of mycelial extracts of Rhizopus stolonifer against different fungal and bacterial pathogenic strains. Int. J. Biosci. 2014; 4(7): 276-281. https://doi.org/10.12692/ $\mathrm{ijb} / 4.7 .276-282$

64. Moore T, Globa L, Barbaree J, Vodyanoy V, Sorokulova I. Antagonistic Activity of Bacillus Bacteria against Food-Borne Pathogens. J Prob Health. 2013; 1: 110. https://doi.org/10.4172/2329-8901.1000110

65. Guo Q, Dong W, Li S, Lu X, Wang P, Zhang X, Wang Y, Ma P. Fengycin Produced by Bacillus subtilis NCD-2 Plays a Major Role in Biocontrol of Cotton Seedling Damping-Off Disease. Microbiol Res. 2014; 169: 533540. https://doi.org/10.1016/j.micres.2013.12.001

66. Li XY, Yang JJ, Mao ZC, Ho HH, Wu YX, He YQ. Enhancement of Biocontrol Activities and Cyclic Lipopeptides Production by Chemical Mutagenesis of Bacillus subtilis XF-1, a Biocontrol Agent of Plasmodiophora brassicae and Fusarium solani. Indian J Microbiol. 2014; 54: 476-479. https://doi. org/10.1007/s12088-014-0471-y

67. Baffoni L, GaggiaF, Dalanaj N, Prodi A, Nipoti P, Pisi A, Biavati B, Di Gioia D. Microbial Inoculants for the Biocontrol of Fusarium spp. in Durum Wheat. BMC Microbiol. 2015; 15: 242. https://doi.org/10.1186/ s12866-015-0573-7

68. Shternshis, MV, Belyaev AA, Matchenko NS, Shpatova TV, Lelyak AA. Possibility of Biological Control of Primocane Fruiting Raspberry Disease Caused by Fusarium sambucinum. Envir Sci Poll Res. 2015; 22: 15656-15662. https://doi.org/10.1007/s11356-0154763-5

69. Caulier S, Nannan C, Gillis A, Licciardi F, Bragard C, Mahillon J. Overview of the Antimicrobial Compounds Produced by Members of the Bacillus subtilis Group. Front Microbiol. 2019 ; 26:10:302. https://doi. org/10.3389/fmicb.2019.00302 